\title{
Genesis of the Logico-Semantic Organization of Adolescents Speech in the Post-Nonclassical Perspective of the Contemporaneity
}

\section{Генеза логіко-смислової організації мовлення підлітків у постнекласичній перспективі сучасності}

\author{
Natalya Tokareva \\ Dr. in Psychology, \\ Assistant Professor, \\ Head of Common and \\ age Psychology Faculty
}

\author{
Наталя Токарева \\ доктор психологічних наук, \\ доцент, \\ завідувач кафедри загальної \\ та вікової психології
}
E-mail: tokareva152681@,gmail.com orcid.org/ 0000-0003-1428-3729

Kryvyi Rih State

Pedagogical University

54, Gagarin, av., Кгуvуi Rih,

Dnepropetrovsk Reg., Ukraine, 50086
ДВНЗ «Криворізький державний педагогічний університет»

$\checkmark$ пр. Гагаріна, 54, м. Кривий Ріг,

Дніпропетровська обл.,

Україна, 50086

Original manuscript received April 01, 2018

Revised manuscript accepted September 10, 2018

\begin{abstract}
The article presents the results of theoretical and empirical analysis of the trends in the speech development of adolescents in the context of psycholinguistic scientific space. As one of the vectors of adolescents' thoughtspeech activity development, the author considers the development of the logical-semantic organization of the speech utterance, which is a complex unity of interrelated but phenomenologically independent phenomena: objectmeaning and logical ordering of speech utterance structure.

The necessity of using the post-neoclassical approach (evolutionarysynergetic paradigm of scientific rationality) to study the trends in the
\end{abstract}


variability of modern adolescents speech development is grounded in the article, which makes it possible to analyze the phenomenological field of speech from the standpoint of the development of open dissipative systems in the unity of the socio-cultural, psychological and psycholinguistic contexts.

Empirical study procedure involves the study of the features of logicalsemantic organization of teenager's speech activity of by the formation of written speech utterance by the method of quasi-creative work with the supports. The subject of analysis were meaningful text content (denotative content presentation units and their hierarchical matching) and logical ordering of the speech utterance structure (proportional correlation of each of the microtopics within the logics of integral text, compliance consistency of information blocks, ensuring communications between first-order predicators). Comparison of the average values of predicators of the psycholinguistic profile of verbal constructs of adolescents of different ages revealed certain differences in the compared groups and showed nonlinearity of the respondents speech development.

The data obtained are interpreted by the author as the conditionality of the schoolchildren' speech development not only by the external situational and contextual influence of the educational process, but also by the specificity of age-related neoplasms of the cognitive spectrum. In this context, the purposeful formation of the communicative culture of an individual, mastery of effective ways of forming and formulating thoughts in the logic of dialogical partnership is defined as an indispensable prerequisite for the personal development of adolescents.

Key words: speech utterance, logical-semantic organization of the text, speech development, teenager, post-neoclassical perspective.

\section{Вступ}

Полісистемні трансформації, прискорення темпів історії, інформатизація та глобалізація суспільних процесів у XXI столітті зумовлюють інтерес наукової спільноти до людини як суб'єкта життєтворчості зі своїми інтелектуальними, мовленнєвими, поведінковими особливостями, i зокрема - до концептів психолого-педагогічного супроводу генези буття людини у період дорослішання. Однією із ключових проблем осмислення сутності психічного розвитку дитини залишається питання формування мовленнєво-мисленнєвої діяльності мовної особистості нового покоління, покоління «next».

Сучасний підліток існує у вимірах агресивних інформаційнокомунікаційних потоків, що детермінує жорстку необхідність 
Genesis of the Logico-Semantic Organization of Adolescents Speech...

відображення накопиченого досвіду людства і власного персонологічного досвіду у мовленнєвій поведінці. Ознаки цивілізації епохи постмодернізму: «розпад універсальної картини світу, криза колективної ідентичності, інтенсивність субкультурної стратифікації, вибух есхатологічних настроїв» (Хренов, 2002: 5) беззаперечно виявляються у мовленні отроцтва, адже мова i мовлення $є$ своєрідними універсаліями, котрі вибудовують простір життєтворення особистості і форматують символічний спосіб комунікації. У своєрідній психолінгвістичній субкультурі підлітків знаходять відображення норми та цінності, що домінують у молодіжному середовищі та $\epsilon$ орієнтирами для вербальної i невербальної поведінки носіїв соціолекту. Особливості мовлення підлітків проявляють себе на фонетичному (артикуляційна модифікація слів), лексичному (лексико-семантичні новоутворення, інвективна лексика різних ступенів стилістичної зниженості) та граматичному (відхилення від норм кодифікованої граматики) рівнях (Боднар, 2004). Означені системні утворення вплетені у процеси сприймання, збереження і передання інформації, вони $\epsilon$ компонентами когнітивної діяльності, зорієнтованої на становлення та регуляцію динамічної смислової системи суб'єкта життєтворення в інформаційному суспільстві. Серед основних ліній розвитку смислової сфери особистості Д.О. Леонтьєв називає ієрархізацію, інтеграцію і структурне ускладнення, а також когнітивне (точніше, ідеаторне) опосередкування смислової регуляції, ऑiі поширення за межі наявної актуально сприйнятої ситуації, безпосереднього перцептивного поля, у план прогнозів, уявлень, ідеаторних змістів свідомості (Леонтьев, 2007: 282-289). У підлітковому віці, коли внутрішній світ та індивідуальні смислові орієнтації набувають ознак самодостатності, смислова регуляція починає нерідко приймати контрадаптивний, або й дезадаптивний характер, конфліктуючи із іншими регуляторними системами (Леонтьев, 2007: 290), індивідуальна траєкторія мовно-мовленнєвого розвитку особистості характеризується поширенням у мовленнєвому контенті неоптимальних (примітивізованих, семантично збіднених) паттернів логіко-смислової структури мовленнєво-мисленнєвої діяльності. Когнітивна природа логіко-смислової організації мовлення спирається на перцептивні і мисленнєві операції, що підтверджує єдність засвоєння дитиною мови і мовлення в онтогенезі 
спільно із розвитком сприймання i розуміння навколишнього світу (Ушакова, 2011: 238). У даному контексті не викликає сумніву актуальність і продуктивність застосування до аналізу мовленнєво-мисленнєвої діяльності підлітків постнекласичного підходу, що дозволяє інтегрувати полімодальний науковий ресурс антропологічної парадигматики задля дослідження складних вимірів смислоформулювання і текстотворення в умовах сучасності.

Принципові засади організації мовленнєво-мисленнєвої діяльності традиційно займають важливе місце у дослідженнях науковців (Chomsky, 1968; Greene, 1972; Slobin, 1971; FourshaStevenson, Schembri, Nicoladis \& Eriksen, 2017; Frank \& Christiansen, 2018; Ахутина, 1989; Калмикова, 2016; Леонтьев, 2007; Ушакова, 2011 та ін.) і становлять особливий інтерес у контексті вивчення логіко-смислової організації мовленнєвого висловлювання (Chrabaszcz \& Gor, 2017; Леонтьев, 2007; Ушакова, 2011; Калмикова, 2016 та інші). Проблема вираження смислу у мовленні $є$ одним із найбільш значущих наукових аспектів вивчення дитячого мовлення у онтопсихолінгвістиці (Ушакова, 2011: 73), адже кожне мовленнєве висловлювання (текст) є проекцією ментального контенту конкретної мовної особистості, котра володіє системою мови і готова до мовленнєвих вчинків. «Опрацьована людиною інформація про навколишній світ, втілена у мовленнєву форму, несе на собі відбиток психіки людини», - підкреслює професор T.М. Ушакова. У тексті, на думку фахівця із вербальної семантики, «розкриваються повноцінні і необмежені можливості для втілення часто дуже складного задуму автора, семантики у широкому сенсі» (Ушакова, 2011: 239-240). Через аналіз текстів, мовленнєвого змісту можна отримати уявлення про структури мислення людини, особливості відображення об'єктивної реальності, світобачення. Водночас, педагогічна практика мовленнєвого розвитку школярів спирається переважно на лінгвістичні моделі (Калмикова, 2016; Токарева, 2014), що перешкоджає оволодінню текстуальними вимірами мовленнєвого простору i ускладнює формування навичок комунікативної діяльності та компетентностей школярів. Найбільш уразливим місцем мовно-мовленнєвої підготовки підлітків є здатність до самостійної побудови смислової структури мовленнєвого висловлювання. 
Genesis of the Logico-Semantic Organization of Adolescents Speech...

Зважаючи на дискусійний контент означеної проблеми, відсутність повноцінної інтегративної теорії розвитку мовної особистості в сучасному освітньому середовищі, а також усвідомлюючи важливість розуміння тенденцій особистісного становлення сучасного підлітка в системі психолого-педагогічного супроводу навчально-виховного процесу, мета даного дослідження була означена нами як конкретизація тенденцій вікової динаміки логіко-смислової організації мовленнєвих висловлювань (далі ЛСОМВ) підлітків у просторі сучасного інформаційного суспільства.

\section{Методи і методики дослідження}

Беручи до уваги, що контекстуальність організації логікосмислової структури мовленнєвого висловлювання формується (у єдності системи «мова - мовлення - мовленнєва діяльність») і закріплюється в процесі життєдіяльності особистості, нами було зроблено гіпотетичне припущення про існування відмінностей у виявленні текстових предикторів мовлення у підлітків різних вікових груп.

Вибірку емпіричного дослідження склали 543 учні 6-9-х класів загальноосвітніх шкіл м. Кривого Рогу (Україна); вік респондентів (11-15 років) детермінований особливостями генези підліткового етапу розвитку у системі освітнього простору.

В основу емпіричного дослідження були покладені результати попереднього теоретичного аналізу проблеми розвитку мовлення (і зокрема - навичок ЛСОМВ) протягом підліткового віку. Конструкт логіко-смислової організації мовленнєвого висловлювання (ЛСОМВ) ми розглядаємо як один із векторів розвитку мовленнєвомисленнєвої діяльності, що є складною єдністю взаємопов'язаних, але феноменологічно самостійних явищ: предметно-смислового (денотативного) і логічного упорядкування (ієрархічного узгодження предикатів) структури мовленнєвого висловлювання.

Полімодальність та варіативність мовленнєвого розвитку особистості у період дорослішання в умовах нестабільності сучасної соціокультурної ситуації зумовили необхідність використання постнекласичного підходу (еволюційно-синергетичної парадигми наукової раціональності), що дозволяє аналізувати феноменологічне поле мовленнєвого розвитку підлітків із позицій розвитку (самоорганізації) відкритих дисипативних 
Генеза логіко-смислової організащї̈мовлення підлітків...

систем у єдності соціокультурного, психологічного та психолінгвістичного контекстів.

Предметом дослідження була обрана логіко-смислова організація письмового тексту (складно організованого мовленнєвого висловлювання) школярів підліткового віку. Зв’язність, цілісність і семантична завершеність розглядалися як основні ознаки текстових одиниць, смисл яких формується із інтеграції усіх мовних елементів, що приймають участь у породженні мовлення (Ушакова, 2011: 239); на рівні тексту втілюється складний задум висловлювання, відбувається взаємодія мови і мислення. Вибір письмової форми мовлення зумовлений ii більшою послідовністю, логічністю розвитку думки, розгорнутістю (оформленістю семантичних і синтаксичних зв'язків) порівняно із усним мовленням, що дозволяє об’єктивувати елементи внутрішньої структури висловлювання, котрі в усній формі мовлення залишаються у внутрішньому плані.

Процедура дослідження передбачала емпіричне вивчення ЛСОМВ підлітків методом утворення письмового мовленнєвого висловлювання за методикою умовно-творчої роботи 3 опорами. Учням пропонувалося на підставі трьох текстів-опор створити власний текст узагальненого характеру. Робота потребувала поетапного когнітивного опрацювання інформації - фреймінгу (Фурс \& Власова, 2013: 101): осмислення і категоризації наданої інформації, здатності свідомо моделювати різні типи мовленнєвих висловлювань із урахуванням причинно-наслідкових залежностей між елементами текстового конструалу та сурядності мікротем, реалізації можливостей оцінювати ментальні репрезентації вторинного тексту. Результатом смислового перекодування сприйнятих повідомлень є його реконструкція і динамічна смислова перебудова залежно від актуальних характеристик породжуваного тексту (смислоорганізованість вербального матеріалу, структура тексту, узгодження смислових кодів суб’єктів комунікації тощо).

Аналізу підлягали предметно-смисловий контент тексту (денотативне представлення змістових одиниць (адекватність репрезентації у тексті окремих сегментів змісту), їх ієрархічне узгодження), що виявляється у психологічній структурі предикатів, котрі втілюють задум висловлювання i забезпечують вираження основної думки, та логічне упорядкування структури мовленнєвого висловлювання (вибудовування ієрархії предикатів, пропорційне 
Genesis of the Logico-Semantic Organization of Adolescents Speech...

співвіднесення кожної 3 мікротем у логіці цілісного тексту, дотримання послідовності викладення інформаційних блоків, забезпечення зв'язку між предикаторами першого порядку).

Первинна обробка даних здійснювалася методом контентаналізу із подальшим обчисленням середньостатистичних значень отриманого матеріалу. При узагальненні та аналізі результатів емпіричного зрізу була використана комп'ютерна статистична програма IBM SPSS Statistics 19 («Statistical Package for the Social Science»).

\section{Результати та дискусії}

У логіці аналізу психологічної організації процесу породження мовлення як послідовності взаємопов'язаних фаз мовленнєво-мисленнєвої діяльності центральна ідея ЛСОМВ може бути виражена загальною формулою: відношення думки до слова $є$ процес трансформації думки у слово і слова - у думку, що пояснює традиційну для психолінгвістики диференціацію процесів смислоформування - стратегії втілення думки у слові i смислоформулювання - стратегії вилучення думки із слова (Леонтьева, 2015: 40). Більш широкий контекст організації мовленнєво-мисленнєвої діяльності детермінує узгодження слів у речення, і далі - у смислове ціле (текст), в межах якого форматується персональний профіль ЛСОМВ конкретної мовної особистості.

Узагальнені результати психодіагностичного вимірювання тенденцій організації логіко-смислової структури мовленнєвого висловлювання в порівнюваних групах підлітків вибіркової сукупності наведені у таблиці 1.

Зіставлення середніх величин $\left(\mathrm{M}_{\mathrm{X}}\right)$ показників психолінгвістичного профілю ЛСОМВ підлітків виявило певні відмінності у порівнюваних групах i засвідчило нелінійність мовленнєвого розвитку респондентів.

Аналіз кількісних показників предметно-смислової організації досліджуваних текстів дозволив констатувати загальну регресивну тенденцію: кількість речень у творчих роботах підлітків із віком зменшується (у молодших підлітків $\mathrm{M}_{\mathrm{X}}=14,6$, у старших підлітків $\left.\mathrm{M}_{\mathrm{X}}=7,6\right)$; послідовність зменшення кількості предикативних елементів у структурі синтаксису текстів руйнується у підлітків 14 років, мовлення яких відзначається зростанням кількості ускладнюючих синтаксичних елементів. 
Генеза логіко-смислової організащї мовлення підлітків...

Таблиця 1. Показники середніх величин профілю ЛСОМВ підлітків

\begin{tabular}{|c|c|c|c|c|}
\hline \multirow{3}{*}{$\begin{array}{l}\text { Параметри } \\
\text { аналізу тексту }\end{array}$} & \multicolumn{4}{|c|}{ Вікові групи респондентів } \\
\hline & $\begin{array}{c}\text { 11-12 років } \\
(\mathrm{N}=135)\end{array}$ & $\begin{array}{l}13 \text { років } \\
(\mathrm{N}=128)\end{array}$ & $\begin{array}{l}14 \text { років } \\
(\mathrm{N}=132)\end{array}$ & $\begin{array}{c}15 \text { років } \\
(\mathrm{N}=148)\end{array}$ \\
\hline & \multicolumn{4}{|c|}{ Середні величини показників ЛСОМВ $\left(\mathrm{M}_{\mathbf{x}}\right)$} \\
\hline Кількість речень & 14,6 & 10 & 11 & 7,6 \\
\hline Кількість предикацій & 21,9 & 14,5 & 23,4 & 14,3 \\
\hline Кількість слів на предикацію & 5,9 & 4,98 & 5 & 5,6 \\
\hline Зв’язність між предикатами & 78,5 & 70,8 & 80,3 & 79 \\
\hline Виділення головної думки & 2,9 & 1,9 & 2,2 & 2,9 \\
\hline Підпорядкування тексту головній думці & 59,6 & 36,7 & 42 & 73,2 \\
\hline Сурядність мікротем & 54,2 & 30 & 42 & 73,2 \\
\hline Послідовність викладення & 63,3 & 27,9 & 47,6 & 84,2 \\
\hline Міжтемна зв’язність & 43 & 24,4 & 32,8 & 71,9 \\
\hline
\end{tabular}

Зіставлення середніх величин $\left(\mathrm{M}_{\mathrm{X}}\right)$ показників психолінгвістичного профілю ЛСОМВ підлітків виявило певні відмінності у порівнюваних групах і засвідчило нелінійність мовленнєвого розвитку респондентів.

Аналіз кількісних показників предметно-смислової організації досліджуваних текстів дозволив констатувати загальну регресивну тенденцію: кількість речень у творчих роботах підлітків із віком зменшується (у молодших підлітків $\mathrm{M}_{\mathrm{X}}=14,6$, у старших підлітків $\left.\mathrm{M}_{\mathrm{X}}=7,6\right)$; послідовність зменшення кількості предикативних елементів у структурі синтаксису текстів руйнується у підлітків 14 років, мовлення яких відзначається зростанням кількості ускладнюючих синтаксичних елементів.

Разом 3 тим, у текстових конструкціях підлітків прослідковується тенденція до зменшення кількості слів у предикативних одиницях, що супроводжується ускладненням синтаксису i ущільненням смислу в системах денотатного представлення змісту (зокрема, у підлітків 14 років $\mathrm{M}_{\mathrm{X}}$ кількості предикацій становить 23,4 одиниці (max по вибірці), тоді як кількість слів на предикацію дорівнює в середньому 5 ( $\max$ по вибірці 5,9$)$ ). Схильність школярів даної вікової групи до скорочення фраз відображує поширення серед підлітків (як носіїв соціолекту) спілкування за допомогою SMS та специфіку «кліпового» мислення, притаманного підлітковій субкультурі. 
Genesis of the Logico-Semantic Organization of Adolescents Speech...

У форматі логічного упорядкування мовленнєвих висловлювань найнижчі показники виявляють підлітки 13 років; в роботах школярів даної вікової групи прослідковуються помилки у формулюванні головної думки (найчастіше - представлення другорядної думки в якості головної), непослідовність розгортання думки за єдиними засадами протягом текстового контенту, необгрунтованість змістом узагальнень та висновків. У 14-15 років зв'язність i сурядність мікротем у тексті, підпорядкованість тексту головній думці та послідовність викладення інформації якісно покращується.

Однофакторний дисперсійний аналіз ANOVA (див. табл. 2), коректність застосування якого перевірено із залученням критерію однорідності дисперсій Лівіня (при $\mathrm{p}>0,05)$, показав, що відмінності між віковими групами підлітків у виявленні ЛСОМВ $\epsilon$ статистично достовірно значущими відносно предикторів логічного упорядкування структури мовленнєвого висловлювання (при $\mathrm{p} \leq 0,05)$ : $\mathrm{M}_{\mathrm{X}}$ порівнюваних величин якісно відрізняються.

Таблиця 2. Параметри статистичної достовірності відмінностей профілю ЛСОМВ між віковими групами респондентів

\begin{tabular}{|c|c|c|c|c|}
\hline \multirow[b]{2}{*}{$\begin{array}{l}\text { Параметри } \\
\text { аналізу тексту }\end{array}$} & \multicolumn{2}{|c|}{$\begin{array}{c}\text { Значення } \\
\text { однофакторного } \\
\text { дисперсійного аналізу }\end{array}$} & \multicolumn{2}{|c|}{$\begin{array}{l}\text { t-критерій рівності } \\
\text { середніх Стьюдента }\end{array}$} \\
\hline & $\begin{array}{l}\text { F-критерий } \\
\text { Фішера }\end{array}$ & $\begin{array}{c}\text { Рівень } \\
\text { значимості } \\
\text { відмінностей } p\end{array}$ & $\mathrm{t}$ & $\begin{array}{c}\text { Рівень } \\
\text { значимості } \\
\text { відмінностей } p\end{array}$ \\
\hline Кількість речень & 6,713 & 0,645 & 0,021 & 0,056 \\
\hline Кількість предикацій & 2,876 & $\mathbf{0 , 0 2 7}$ & 0,497 & 0,001 \\
\hline Кількість слів на предикацію & 4,609 & 0,072 & 0,104 & 0,671 \\
\hline Зв'язність між предикатами & 2,968 & 0,023 & 0,466 & 0,001 \\
\hline Виділення головної думки & 1,897 & $\mathbf{0 , 0 1 7}$ & 0,117 & 0,050 \\
\hline $\begin{array}{l}\text { Підпорядкування тексту } \\
\text { головній думці }\end{array}$ & 5,122 & 0,001 & 0,441 & 0,001 \\
\hline Сурядність мікротем & 1,973 & $\mathbf{0 , 0 3 8}$ & 0,625 & 0,050 \\
\hline Послідовність викладення & 3,626 & 0,001 & 0,481 & 0,001 \\
\hline Міжтемна зв’язність & 7,305 & 0,026 & 0,552 & 0,001 \\
\hline
\end{tabular}

Рівень проявів $\mathrm{M}_{\mathrm{X}}$ за шкалами «Кількість речень» і «Кількість слів на предикацію» у порівнюваних групах не має статистично значущих відмінностей $(\mathrm{p}>0,05)$, що свідчить про відносну 
сталість параметрів денотатного представлення змістових одиниць у мовленнєвих висловлюваннях підлітків різного віку, а отже помилки у предметно-смисловому аспекті текстотворення підлітків пов'язані не із віковими особливостями розвитку мовленнєво-мисленнєвої діяльності, a із індивідуальною недостатністю мовленнєвої культури респондентів.

В умовах передбаченої рівності дисперсій $\mathrm{t}$-критерій Стьюдента для незалежних вибірок (p-рівень $\leq 0,05)$ також зафіксував статистичну значущість відмінностей у логічному упорядкуванні структури мовленнєвого висловлювання $(\mathrm{p}=0,0001 \leq 0,05)$ між підлітками різного віку. Кореляційний аналіз виявив наявність взаємозв'язків між змінними «Вікові групи» та параметрами ЛСОМВ підлітків, сила яких дозволяє виокремити дві підгрупи кореляцій: 1) взаємозв'язок слабкої сили $(\mathrm{t} \leq 0,3)$ між змінними «Вікові групи» та контент-блоком «Виділення головної думки» $(\mathrm{t}=0,117)$ на достатньому рівні статистичної значущості $(\mathrm{p} \leq 0,05)$, що характеризує потенційні тенденції прогресивного розвитку логічного мислення особистості у період дорослішання; 2) взаємозв'язки помірної сили $(0,3 \leq \mathrm{t} \leq 0,7)$ між змінними «Вікові групи» та контент-блоками «Зв'язність між предикатами» $(\mathrm{t}=0,466)$, «Підпорядкування тексту головній думці» $(\mathrm{t}=0,441)$, «Сурядність мікротем» $(\mathrm{t}=0,625)$, «Послідовність викладення» $(\mathrm{t}=0,481)$ та «Міжтемна зв'язність» $(\mathrm{t}=0,552)$ на достатньому $(\mathrm{p} \leq 0,05)$ та середньому $(\mathrm{p} \leq 0,01)$ рівнях статистичної значущості. А отже можна стверджувати, що саме параметри логічної організації висловлювання достовірно змінюються у процесі мовленнєвого розвитку школярів протягом вікового періоду генези буття.

В цілому ж динаміка ЛСОМВ у підлітковому віці не має чітко вираженого позитивного вектору розвитку і відображує дві тенденції: регресивну (11-13 років), що характеризується збільшенням порушень (викривлень або й руйнації) лексикопонятійної, граматичної та логіко-смислової структур тестового повідомлення, та прогресивну (14-15 років), котра означує зменшення помилок під час текстотворення. Найбільш проблемним періодом розвитку мовленнєво-мисленнєвої діяльності, пов'язаної із специфікою ЛСОМВ, виявився період 13 років, коли у системі організації логіко-смислового мовленнєвого контенту підлітків виявляються суперечливі тенденції: структурне ускладнення 
синтагматичних одиниць мовлення, що виражається у все більш частому вживанні складних синтаксичних конструкцій, розширенні сфери використання слів складної морфологічної структури, поєднується із уніфікацією засобів мовлення, зменшенням їх різноманітності, що призводить до стандартизації мовлення школярів даної вікової групи.

В контексті постнекласичного інтеграційного підходу до розуміння психологічної сутності ЛСОМВ підлітків отримані дані засвідчують зумовленість мовленнєвого розвитку школярів не лише зовнішнім ситуативно-контекстуальним впливом навчального процесу, але й специфікою вікових новоутворень мовнокогнітивного спектру.

Постнекласична парадигма сучасного інформаційного суспільства епохи постмодернізму, сповнена фрагментарністю (полістилістикою) буття, радикальним плюралізмом у розумінні персональних наративів, ситуаційною невизначеністю контекстів, акцентованою поліваріативністю у ставленні до культурних традицій, гетерогенністю смислів, рівнів розуміння тексту (хронотопів, реалій буття, екзистенційних конструкцій), що перетворює наративи у ребуси, загадки, розв'язання яких залежить від фантазії, ерудиції, персональної культури суб'єкта, значно ускладнює розвиток логічного мислення дитини. Пріоритетність ігрових сценаріїв життєтворення у період дорослішання гарантує підліткам відкритість простору самоздійснення, звільнення від цілепокладання, можливість добудовувати смисли, використовуючи неочікувані асоціації, свободу бунтівного нормотворення, i, разом 3 тим, знижує ефективність ЛСОМВ (що $є$ особливо значущим у піковий період пубертатної кризи 13 років, котрий супроводжується бурхливими психофізіологічними змінами на фоні гормональних збурень). Через недосконалість ЛСОМВ підліток не завжди готовий i не у всіх випадках життєдіяльності здатний адекватно вербалізувати рівень персональних домагань, через що його відносини із середовищем практично завжди емоційно напружені i динамічні. А отже одним із важливих завдань психолого-педагогічного супроводу дитини в нестабільних умовах соціокультурних трансформацій $\epsilon$ переформатування полісуб'єктних взаємин між дітьми і дорослими у логіко-семантичному полі толерантного паритетного діалогу. 
Суб'єктивні виміри діалогічної реальності стверджуються через мову і мовлення, що $є$ об’єктивними каналами узгодження персонального досвіду особистості у період дорослішання iз ментальним контентом соціокультурного простору: маючи можливість виходити за межі «тут і зараз», мовлення погоджує різні зони реальності повсякденного життя і інтегрує їх у значиме ціле. У межах функціонування постнекласичного освітнього простору (Петренко, 2016) як системного утворення, зорієнтованого на розширення особистісного досвіду, становлення життєвих смислів людини та інтеріоризацію цінностей соціокультурного середовища у змінних умовах буття, найбільш доречними є суб'єктна (аксіальна) та інтерсуб’єктна парадигми організації міжособистісної взаємодії партнерів по спілкуванню (зокрема у системі «вчитель - учень») у континуумі формування навичок повноцінної логіко-смислової організації мовленнєвої діяльності.

\section{Висновки}

Осмислення результатів даного емпіричного дослідження підтверджує, що феномен становлення особистості у динамічному соціокультурному просторі $є$ амбівалентним і полісистемним; це зумовлює необхідність вивчення логіко-смислової організації мовлення підлітків як іманентного способу суб'єктогенезу особистості, зміст якого акумулює вектори соціального і психічного розвитку людини у постнекласичній перспективі. У даному контексті цілеспрямоване формування комунікативної культури особистості (Токарева, 2014), оволодіння ефективними способами формування i формулювання думки в логіці діалогічного партнерства (що забезпечує ментальне та мовно-мовленнєве моделювання дійсності) $\epsilon$ необхідною передумовою особистісного розвитку.

Практика мовленнєво-мисленнєвого розвитку особистості у період дорослішання як перманентний багаторівневий процес формування, актуалізації, упорядкування (багатоваріантного розширення i уточнення) патернів суб'єктивного досвіду ЛСОМВ особистості може здійснюватися у двох напрямах: активізації потенційних можливостей суб'єкта (внутрішня детермінація персональних ресурсів логічного оформлення схем смислоформування i текстотворення) i цілеспрямованого соціально-психологічного стимулювання адекватної мовленнєвої 
Genesis of the Logico-Semantic Organization of Adolescents Speech...

поведінки (зовнішня детермінація навичок цілепокладання, смислоформулювання, послідовності і логічності викладення думок, ієрархізації контекстів) у суб'єктивно валідних форматах. Атракторами процесу розвитку мовленнєво-мисленнєвої діяльності нами визнано механізми смислотворення (ментальної реконструкції) комунікативного контуру висловлювань у ситуації діалогу (введення нових значень до особистісного поля, модифікація структури значень, реструктуризація смислового поля у цілому для змінення ставлення до навколишньої дійсності, логічна ієрархізація синтагматичних структур тексту). Активність підлітків у процесах суб'єктивного самоздійснення у вимірах мовленнєво-мисленнєвої діяльності детермінована об'єктивними можливостями та потребами віку у верифікації потенційних ресурсів комунікативної поведінки, успішність якої пов'язана із ефективністю логіко-смислової організації мовленнєвих конструкцій.

Підводячи підсумки дослідження необхідно відзначити, що в процесі роботи над проблемою ЛСОМВ підлітків отримали подальший розвиток знання про основні тенденції мовномовленнєвого розвитку дитини у період дорослішання. Практичне значення представлених у даному дослідженні результатів вивчення ЛСОМВ підлітків полягає у широких можливостях використання теоретико-емпіричних положень i сформульованих на їх основі психологічних висновків для цілеспрямованого моделювання кваліфікованої психолого-педагогічної підтримки школярів період дорослішання.

Виконане дослідження не вичерпує всіх аспектів проблемного поля генези логіко-смислової організації мовлення підлітків, але відкриває перспективи для подальшого його вивчення: дослідження когнітивних механізмів мовотворення у підлітково-юнацькому середовищі, звернення до гендерного аспекту використання комунікативних стратегій у різних ситуаціях мовленнєвої взаємодії.

\section{Література}

Ахутина, Т.В. Порождение речи. Нейролингвистический анализ синтаксиса. Москва : Изд-во Моск. ун-та, 1989. 215 с.

Боднар, Р.В. Соціолект підлітків як об’єкт лінгвістичних досліджень (на матеріалі англійської мови). Мовні $і$ концептуальні картини світу: Зб. наук. праць. Київ : КНУ ім. Т. Шевченка ; ВПУ «Київський університет», 2004. Вип. 10. C. $45-50$. 
Калмикова, Л.О. Формування у дітей старшого дошкільного віку мовленнєвої діяльності: діагностико-розвивальний комплекс. Київ : Видавничий Дім «Слово», 2016. 384 с.

Леонтьев, Д.А. Психология смысла: природа, строение и динамика смысловой реальности. Москва : Смысл, 2007. 511 с.

Леонтьева, А.В. Рефлексия в ментальном и языковом конструировании действительности: предпосылки и грани семантической диффузности. Bопросы когнитивной лингвистики. 2015. Вып. 2 (043). С. 40-45.

Петренко, О.Б. Постнекласична парадигма освіти й виховання: Теоретичний аналіз. Інноватика у вихованні. 2016. Вип. 3. С. 40-49.

Токарева, Н.Н. Развитие коммуникативной компетентности личности подростка. Scientific Papers of The Witelon State University of Applied Sciences in Legnica. 2014. Вып. 12 (3). С. 57-66.

Ушакова, Т.Н. Рождение слова: Проблемы психологии речи и психолингвистики. Москва : Институт психологии РАН, 2011. 524 с.

Фурс, Л.А., Власова, К.В. Моделирование комплиментарности как типа убеждающей коммуникации. Bonpocbl когнитивной лингвистики. 2013. Вып. 1 (034). С. 100-105.

Хренов, Н. Культура в эпоху социального хаоса. Москва : Эдиториал УРСС, 2002. 448 c.

Chomsky, N. (1968). Language and Mind. New York: Harcourt Brace Jovanovich Inc.

Chrabaszcz, A., \& Gor, K. (2017). Quantifying contextual effects in second language processing of phonolexically ambiguous and unambiguous words. Applied Psycholinguistics, 38 (4), 909-942. DOI: 10.1017/S0142716416000497

Foursha-Stevenson, C., Schembri, T., Nicoladis, E., \& Eriksen, C. (2017). The influence of child-directed speech on word learning and comprehension. Journal of Psycholinguistic Research, 46 (2), 329-343. DOI: 10.1007/s10936-016-9441-3

Greene, J. (1972). Psycholinguistics. Chomsky and Psychology. New York : Penguin Books.

Slobin, Dan I. (1971). Psycholinguistics. Illinois: Glenview \& London : Scott, Foresman and Co.

Frank, St.L., \& Christiansen, M.H. (2018). Hierarchical and sequential processing of language. Language, Cognition and Neuroscience, 33 (9), 1213-1218. DOI:10.10 $80 / 23273798.2018 .1424347$

\section{References}

Ahutina, T.V. (1989). Porozhdenie rechi. Nejrolingvisticheskij analiz sintaksisa [Generation of speech. Neurolinguistic analysis of syntax]. Moscow : Izd-vo Mosk. un-ta [in Russian].

Bodnar, R.V. (2004). Sociolekt pidlitkiv jak ob'yekt lingvistichnih doslidzhen (na materiali anglijskoï movi) [Sociolekt of adolescents as an object of linguistic research (on the material of the English language)]. Movni $i$ konceptualni kartini svitu - Linguistic and Conceptual Worldviews, 10, 45-50 [in Ukrainian].

Kalmkova, L.O. (2016). Formuvannja u ditej starshogo doshkilnogo viku movlennevoï dijalnosti: diagnostiko-rozvivalnij kompleks [Formation in children of the senior preschool age of speech activity: diagnostic-development complex]. Kyiv : Vidavnichij Dim «Slovo» [in Ukrainian]. 
Genesis of the Logico-Semantic Organization of Adolescents Speech...

Leontev, D.A. (2007). Psihologija smysla: priroda, stroenie $i$ dinamika smyslovoj realnosti [Psychology of meaning: nature, structure and dynamics of the semantic reality]. Moskow : Smysl [in Russian].

Leonteva, A.V. (2015). Refleksija v mentalnom i jazykovom konstruirovanii dejstvitelnosti: predposylki $\mathrm{i}$ grani semanticheskoj diffuznosti [Reflection in the mental and linguistic construction of reality: the prerequisites and facets of semantic diffusion]. Voprosy kognitivnoj lingvistiki - Questions of Cognitive Linguistics, 2 (043), 40-45 [in Russian].

Petrenko, O.B. (2016). Postneklasichna paradigma osviti j vihovannja: Teoretichnij analiz [The post-informal paradigm of basic knowledge: Theoretical analysis]. Innovatika $u$ vihovanni - Innovation in upbringing, 3, 40-49 [in Ukrainian].

Tokareva, N.N. (2014). Razvitie kommunikativnoj kompetentnosti lichnosti podrostka [Development of communicative competence of the adolescent's personality]. Scientific Papers of The Witelon State University of Applied Sciences in Legnica, 12 (3), 57-66 [in Russian].

Ushakova, T.N. (2011). Rozhdenie slova: Problemy psihologii rechi i psiholingvistiki [Birth of the word: Problems of speech psychology and psycholinguistics]. Moskow : Institut psihologii RAN [in Russian].

Furs, L.A., \& Vlasova, K.V. (2013). Modelirovanie komplimentarnosti kak tipa ubezhdajushhej kommunikacii [Simulation of complementarity as a type of persuasive communication]. Voprosy kognitivnoj lingvistiki - Questions of Cognitive Linguistics, 1 (034),100-105 [in Russian].

Hrenov, N. (2002). Kultura v jepohu socialnogo haosa [Culture in the era of social chaos]. Moskow : Jeditorial URSS [in Russian].

Chomsky, N. (1968). Language and Mind. New York: Harcourt Brace Jovanovich, Inc.

Chrabaszcz, A., \& Gor, K. (2017). Quantifying contextual effects in second language processing of phonolexically ambiguous and unambiguous words. Applied Psycholinguistics, 38 (4), 909-942. DOI: 10.1017/S0142716416000497

Foursha-Stevenson, C., Schembri, T., Nicoladis, E., \& Eriksen, C. (2017). The influence of child-directed speech on word learning and comprehension. Journal of Psycholinguistic Research, 46 (2), 329-343. DOI: 10.1007/s10936-016-9441-3

Greene, J. (1972). Psycholinguistics. Chomsky and Psychology. New York : Penguin Books.

Slobin, Dan I. (1971). Psycholinguistics. Illinois : Glenview, \& London : Scott, Foresman and Co.

Frank, St.L., \& Christiansen, M.H. (2018). Hierarchical and sequential processing of language. Language, Cognition and Neuroscience, 33 (9), 1213-1218. DOI:10.10 80/23273798.2018.1424347

\section{АНОТАЦІЯ}

У статті представлено результати теоретичного та емпіричного аналізу тенденцій мовленнєвого розвитку підлітків у контексті психолінгвістичного наукового простору. В якості одного із векторів розвитку мовленнєво-мисленнєвої діяльності підлітків автор розглядає розвиток логіко-смислової організації мовленнєвого висловлювання, що $\epsilon$ складною єдністю взаємопов'язаних, але феноменологічно самостійних 
явищ: предметно-смислового і логічного упорядкування структури мовленнєвого висловлювання.

у статmі обгрунтовано необхідність використання постнекласичного підходу (еволюційно-синергетичної парадигми наукової раціональності) до вивчення тенденцій варіативності мовленнєвого розвитку сучасних підлітків, що дозволяє аналізувати феноменологічне поле мовлення із позицій розвитку відкритих дисипативних систем у єдності соціокультурного, психологічного та психолінгвістичного контекстів.

Процедура емпіричного дослідження передбачала вивчення особливостей логіко-смислової організації мовлення підлітків методом утворення письмового мовленнєвого висловлювання за методикою умовно-творчої роботи з опорами. Аналізу підлягали предметносмисловий контент тексту (денотатне представлення змістових одиниць та їх ієрархічне узгодження) та логічне упорядкування структури мовленнєвого висловлювання (пропорційне співвіднесення кожної з мікротем у логіці цілісного тексту, дотримання послідовності викладення інформаційних блоків, забезпечення зв'язку між предикаторами першого порядку). Зіставлення середніх величин предикторів психолінгвістичного профрілю мовленнєвих конструктів підлітків різного віку виявило певні відмінності у порівнюваних групах $і$ засвідчило нелінійність мовленнєвого розвитку респондентів.

Отримані дані інтерпретуються автором як зумовленість мовленнєвого розвитку школярів не лише зовнішнім ситуативноконтекстуальним впливом навчального процесу, але й специфікою вікових новоутворень когнітивного спектру. у даному контексті цілеспрямоване формування комунікативної культури особистості, оволодіння ефективними способами фрормування і формулювання думки в логіці діалогічного партнерства визначається як необхідна передумова особистісного і мовно-мовленнєвого розвитку підлітків.

Ключові слова: мовленнєве висловлювання, логіко-смислова організація тексту, мовленнєвий розвиток, підлітковий вік, постнекласична перспектива.

Токарева Наталья. Генезис логико-смысловой организации речи подростков в постнеклассической перспективе современности

\section{АННОТАЦИЯ}

В статье представлены результаты теоретического и эмпирического анализа тенденций речевого развития подростков в контексте психолингвистического научного пространства. В качестве одного из векторов развития речемыслительной деятельности подростков 
Genesis of the Logico-Semantic Organization of Adolescents Speech...

автор рассматривает развитие логико-смысловой организации речевого высказывания, являющейся сложным единством взаимосвязанных, но феноменологически самостоятельных явлений: предметно-смыслового и логического упорядочения структуры речевого высказывания.

В статье обоснована необходимость использования постнеклассического подхода (эволюционно-синергетической парадигмы научной рациональности) к изучению тенденций вариативности речевого развития современных подростков, позволяющего анализировать феноменологчческое поле речи с позиций развития открытых диссипативных систем в единстве социокультурного, психологического и психолингвистического контекстов.

Процедура эмпирического исследования предусматривала изучение особенностей логико-смысловой организации речи подростков методом создания письменного речевого высказывания по методике условно-творческой работы с опорами. Анализу подлежали предметно-смысловой контент текста (денотатное представление содержательных единии и их иерархическое согласование) и логчческое упорядочение структуры речевого высказывания (пропорциональное соотнесение каждой из микротем в логике целостного текста, соблюдение последовательности изложения информационных блоков, обеспечение связи межуу предикаторами первого порядка). Сопоставление средних величин предикторов психолингвистического профиля речевых конструктов подростков разного возраста выявило определенные различия в сравниваемых группах и показало нелинейность речевого развития респондентов.

Полученные данные интерпретируются автором как обусловленность речевого развития школьников не только внешним ситуативно-контекстуальным влиянием учебного процесса, но и спецификой возрастных новообразований когнитивного спектра. В данном контексте целенаправленное формирование коммуникативной культуры личности, овладение эфрфективными способами формирования и формулирования мысли в логике диалогчческого партнерства определяется как необходимая предпосылка личностного развития подростков.

Ключевые слова: речевое высказывание, логико-смысловая организация текста, речевое развитие, подростковый возраст, постнеклассическая перспектива. 